IRA-International Journal of Education \& Multidisciplinary Studies

ISSN 2455-2526; Vol.03, Issue 03 (2016)

Institute of Research Advances

http://research-advances.org/index.php/IJEMS

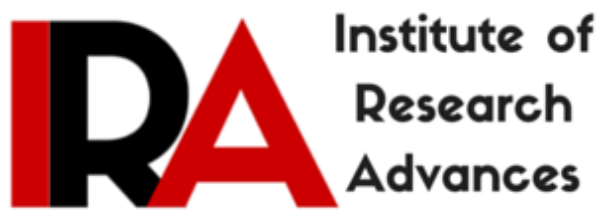

\title{
Can Care and Compassion-Be the Ultimate Solution of Terrorism?
}

\author{
Dr. Urmi Ray \\ Assistant Professor \\ Department of Philosophy \\ Women's Christian College, Kolkata, India. \\ DOI: http://dx.doi.org/10.21013/jems.v3.n3.p20
}

\section{How to cite this paper:}

Ray, U. (2016). Can Care and Compassion-Be the Ultimate Solution of Terrorism?. IRA International Journal of Education and Multidisciplinary Studies (ISSN 2455-2526), 3(3). doi:http://dx.doi.org/10.21013/jems.v3.n3.p20

(C) Institute of Research Advances

\section{(cc) EY-NC}

This works is licensed under a Creative Commons Attribution-Non Commercial 4.0 International License subject to proper citation to the publication source of the work.

Disclaimer: The scholarly papers as reviewed and published by the Institute of Research Advances (IRA) are the views and opinions of their respective authors and are not the views or opinions of the IRA. The IRA disclaims of any harm or loss caused due to the published content to any party. 
Like a number of serious problems in our world terrorism is also one of them. Now what do we mean by; 'terrorism'? It is a political phenomenon, where violence and bloodshed are brought upon the innocent citizens in order to shaken up the Government as it exploits the so-called terrorists. This is a set up which runs parallel with the main stream to devastate the main stream, in a secretive or clandestine method. Thus any violent bloodshed such as killing in robbery or insurgency cannot be called terrorism as there either the cause is not political as in case of killing in robbery; or common men are not targeted as in case of insurgency (although its cause is political). Again Guerilla tactic although is a clandestine or secretive method still it is not terrorism as here the units of the Government, that is innocent citizens are not killed. Revolution also involves violence but unlike terrorism it gains public support. The terrorists claim that they are actually waging a war against the Government, but in a war certain just rules are followed which states that proportionality between the means and end should be maintained, there should be a legitimate authority waging a war, it goes on within a particular territory, it should have a consistent success rate and most importantly it protects the immunity of the innocent mass. But in terrorism such rules of just war are lacking. Thus terrorism is a political violence between the mighty and the weak, for which it can also be called a class struggle or power struggle, where the weak sect shake the mighty by attacking upon those who are part and parcel of the mighty. This 'ism' is thus different from war, insurgency, revolution, crime and guerilla tactic because of its distinct feature that it does not attack its direct victim but attacks its indirect victim. In other words instead of destroying the Government which is guilty to them it attacks the innocent citizens of the Government because they are the units of the Government. Thus if the part is destroyed then the whole would automatically be shaken up. This unique mentality is found only in this 'ism' thus it differs from all other instances of violence. Terrorism is of two types-Terrorism from Above and Terrorism from Below. The former is also known as 'State Sponsored Terrorism' where the state is found to torture its citizens. The latter is termed 'Non-State Terrorism' where the exploited lot terrorizes the state for having been oppressed by it for years. The Non-State Terrorism is formed by the private parties such as Al Qaeda, Aum Shinrikyo, Maoists of India and so on.

So the main problem is that in the name of rebellion they are simply killing the common men, in other words citizens of the Government to shaken up the ruling party. Innocent killing can in no way do well to any one moreover it can be justified by no logic under the sky. How then to solve the problem?

In order to solve the above problem in the light of philosophy, I have used 'Care' -a notion of contemporary western 'Care Ethics' and

Karu $n \overline{\mathrm{a}}$ (compassion), one of the four immeasurables of Buddhist

Ethics. Here care means 'protection', while compassion means 'fellowfeeling'. When I develop a fellow-feeling towards humanity at large then I ought to protect them as we protect ourselves in crisis out of sheer, herein lies the relation between 'Care' and 'Compassion'.

The bad-lives (as Ted Honderich in his book After the Terror calls the underprivileged and the so called exploited lot) should be thus treated with care and compassion. We have to look at their problem from their perspective and treat them with love and care realizing that they are doing such things out of their sufferings. At this juncture we have to introduce 'Ethics of Care', a contemporary branch of Modern ethics to solve this problem. 
Virgina Held, the woman care ethicist in her book The Ethics of Care states that all individuals are interdependent for achieving their interests. Those particularly vulnerable to one's own choices and their outcomes deserve extra consideration to be measured according to a) the level of their vulnerability to one's choices, b) the level of their affectedness by one's choice and no one else's. It is thus necessary to attend to the contextual details of the situation in order to safeguard and promote the actual specific interests of these deprived beings.

The traditional ethics does not take care of specific cases and circumstances; this is where care ethics bridges the gap. Moreover we have to remember that life is neither black nor white, the gray area has to be taken into consideration which is looked after by the 'Ethics of Care'. The ethics of care is a normative ethical theory, a theory about what makes actions right and wrong; not by taking the Universalized standards as found in traditional theories of Utilitarianism and Deontology but by emphasizing the importance of 'Response'. The shift in moral perspective is manifested by a change in moral question from "what is just" to "how to respond?" Such a Care Ethics developed by the feminists in the second half of the $20^{\text {th }}$ century criticizes the applications of universal standards as "morally problematic, since it breeds moral blindness or indifference" as stated by Carol Gilligan in the book Moral Orientation and Moral Development. The Feminist Philosophy Reader by Alison Bailey and Chris J.Cumo (Mc Graw-Hill 2008.P.471).

\section{The terrorists and the traditional theories of Ethics}

Can Deontological theory really provide justice to the so-called terrorists? This theory of traditional ethics speaks of hard-core 'duty' generated by the good will which is dictated by the pure reason. Here a military personnel on being enquired by his friend's mother who is at death bed, about his friend who happens to be her son at war, should tell the truth that he has died, knowing fully the hard consequences which the diseased mother could face on listening the news. As here the consequence of an action does not matter. Similarly it is the duty of the terrorists to obey social laws and revere to the State or Government even if it exploits them, snatches away their rights and gives deaf ears to their basic claims. Here although duty is performed by the terrorists but do such duties provide justice to their suffering souls? Are such duties not making them deprived of their rights, can these duties be called moral?

Again the theory of Utilitarianism states morality is that which gives maximum benefits to maximum number of people in the society. But the terrorists being the minority does not get such maximum benefit, as the rule only goes for the majority.

The theories of Individualitarianism as well as Libertarianism (which are contemporary) also fail to fulfil the needs of the so-called terrorists. Do these terrorists actually get freedom to exercise their individuality amidst such poverty where their basic rights are taken away? Can they express their individuality by being audible to the Government about lack of their basic necessities? Do we identify their existence who live below the poverty line in our country? Do we care for their individuality who are subject to lack of power, economically or otherwise, for one who struggles to survive with a bad or cut-short life? Thus such theories fail to make them stand on their feet as they are only for the mighty.

Their basic right to live on this earth as others, with equality and sovereignty are snatched away from them; their rights to food, shelter and clothing are also taken away from them - in that case how is 'Libertarianism' which sanctions equal liberty to all, helping them?

Hence Care Ethics is introduced; where goodness or badness of an action are taken not by seeing what standard rules, all are following but by seeing how an individual 
responds in a particular situation, how he relates to the others in society and whether he is careful in sustaining the sentiments of others as they are valuable to the others, as are valuable to him.

In the book In a Different Voice Carol Gilligan claims that, for a variety of cultural reasons and for the very reason that she is a mother, women tend to espouse an ethics of care that stresses on relationships and responsibilities, whereas men tend to espouse an ethics of justice that stresses on rules and rights.

To establish the truth of the above mentioned claim an example can be cited ${ }^{1}$.

In a Kohlbergian Experiment, Gilligan shows that a boy and a girl of ten years respond differently when asked what should a husband do if his wife is in death bed and the shopkeeper of the medicine shop refuses to give him a life saving drug as he did not possess the expense for it; should he then steal the medicine? The boy replied yes, but the girl told, that would affect the relationship of that husband and wife so he should not steal. Here the boy emphasized on practicality of the problem but the girl on the relational aspect of human behaviour which entails care in it.

Care, sacrifice, compassion, love, tolerance of women should also be adopted by men, instead of seeing them as foolish, feeble and feminine traits; for a peaceful coexistence in this world, which would perhaps minimize the problem of terrorism. 'Care' has always been seen as the quality of the weak, of the slave (in master-slave morality of Nietzsche). But if the 'masters' or the strong can imbibe this quality then even the unequal relations like that of master-slave, bourgeois-proletariat, doctorpatient, teacher-student can reach their highest forms strengthening the base of any society.

Sara Ruddick and Virginia Held use a maternal perspective to expand Care Ethics as a moral and political theory leading to peace and virtue - as maternity curbs any form of violence. (While some mothers support violence, but they should not; as it frustrates the goal of their substance of care).

We usually care for our near and dear ones, few times for our neighbours and very little for strangers. If my little finger is injured then I keep on brooding about it the whole night whereas we are least bothered with the thousands dying in the earthquake at Japan.

Care Ethics becomes problematic of its political implications for social justice. For example, in U.S women of colour and white women are differently situated in terms of who is more likely to give and receive care and of what degree and quality, as there the care workers continue to be the women of colour.

Martha Nussbaum, the feminist author, like Carol Gilligan, also speaks of care and compassion to all human beings irrespective of gender, class or creed. But such care can be wrongly placed or taken advantage of. In this context Nussbaum gives four judgments - judgment of seriousness, judgment of non-desert, judgment of similar possibilities and eudemonistic judgment as mentioned in Cultivating Humanity (1997, Harvard University Press).

We need not care for a criminal being hung for some heinous crime as per judgment of non-desert, or care for an industrialist losing his toothbrush as per judgment of seriousness, or care for someone just because both of our situations are similar as per judgment of similar possibilities and for one who suffers due to being overtly emotional as per eudemonistic judgment. This is because all such sufferings are not undeserved and we should care only for the 'undeserved suffering'.

Now we would mention some arguments which would show us why care and compassion are required to be imparted to the deprived lot. These arguments would perhaps at once draw our attention, care and compassion towards them. 
P.E Devine and R.J Rafalko in their article called "On Terror" published in The Annals (Volume 463) have considered Three Arguments in favour of the terrorists. They are:-

1. Economy of Scale: The terrorists comprise basically the bad, cut-short and underprivileged lives. Moreover their voice is neither heard by us nor by the Government. Thus taking of arms is their last resort, when the Government fails to hear them and keep them ignored because they are powerless. Now to have a war against such a Government is a costly affair, rather terrorism is much cheap as well as a necessary step to curb exploitation and corruption of the Government. Thus they are compelled to use this 'ism'.

From this argument it is clearly understood that these terrorists lack identification if not celebration of their identity; hence they choose terrorism as their last weapon to draw the attention of the Government. They do not have that economic back up to fight against the Government by using Democratic laws or such that they can carry out a process of election (to overpower the Government) or wage a war to do away with the Government. Their helplessness is evident here. This also shows lack of care from their states' end towards them for which they have to adopt a parallel set up to make them noticed. Since they are ignored and not taken care of hence they use such secretive methods, as secrecy comes with non-acceptance by the main stream. We usually go for cheap things not only because they are easily available but also because they are easily affordable to us. As we cannot opt for something of a better qualityhence we are already at a compromised position (as the proverb goes beggars cannot be choosers). Such is the condition of the terrorists which should spontaneously produce some compassion in us towards them.

2. Consciousness Raising Argument: The terrorists say that when the citizens are in their slumber (as they are the guarded lot of the Government) and the Government turns its face off from the terrorists and their problems; then in order to arouse both the Government and the citizens from their ignorance, terrorism is used as the last resort. We are busy with our own lives and unless we are affected, and unless our turn comes we remain in the unconscious level as far as others' suffering is concerned, remaining preoccupied by our extravagances of lives. This once again shows lack of care from us, to them.

3. Collective Guilt Argument: The terrorists point out that if they are labelled to be guilty then the Government as well as the citizens are guilty. The Government is guilty because it exploits its citizens and the citizens are guilty because they join hands with the Government and succumb to its crimes. In a society where everyone is corrupt and guilty, there no particular sect needs to be promoted as bad or sinful. Once again their sentiment, pain and suffering have to be felt through such an argument. Instead of caring for their problem and trying to help them out we the society simply play a blame-game with them and hence they retaliate. The problem in today's society is that every one of us accuses the others for not being good, but we forget to check whether we are being good or not.

Just as a child tries to draw the attention of the parents by different means when he is not getting it, similarly the terrorists carry out this 'ism' for not getting proper care from us or the Government, thereafter explaining their acts with the above arguments.

Thus what the terrorists are craving for is what they are lacking in, i.e., love, affection, care and compassion. A boy whose parents die in a terrorist attack and a man who is hated for being poor or for having a bad life or because he is from the minority etc.- - here both of them need our care and concern in order to be a part of 'us' and not 'them' as we often alienate the so-called deprived lot whose lives' course of events are not smooth like ours. But many are of the opinion that the victims of the terrorists and not the terrorists (who kill the innocents brutally), require care from us. 
It may be replied that actually both the terrorists and their victims suffer, but as the nature of suffering varies thus the nature of care provided to each also differs. The terrorists suffer since the Government gives a deaf ear to their claims but the victims suffer due to their loss of near and dear ones, sometimes even they are injured physically (limbs are gone in the attack) as well as health wise (bio terrorism- anthrax attacks leading to cancer), leaving aside their mental and material loss. In case of terrorists with care and concern for them we can return them with what they deserve, such as their rights, basic necessities to have a good life etc. but however much care be taken for the victims of terrorists by us, we can never repay their losses of their health, kin and kith - but here we should provide them with the post traumatic care so that they can overcome the trauma as soon as possible and get back to normalcy.

Further in an article of R.M Hare called "On Terrorism" published in the Journal of Value Enquiry edited by E. Laszlo and J. Wilbur (P. 246), the author had given an argument which should actually shaken our compassionate minds. The argument goes like this:-

Either the terrorists must be prepared to use sufficient force against the representatives of the state to dislodge it from power, or he must resign himself to live as an internal alien in a world shaped by state power. (Major premise)

It is well known that the terrorists' strength is not a match to confront the state and its machinery; they therefore adopt clandestine methods. (Minor premise)

Therefore, he must refrain from his political plans to dislodge the state from its power by use of violent or hostile means. (Conclusion)

The argument may be logically formed as:-

$\mathrm{p} \vee \mathrm{q}$

Not $\mathrm{p}$

$\therefore \mathrm{q}$.

$\mathrm{P}=$ terrorists must be able to use sufficient force against the representatives of the state to dislodge it from power.

$q=$ he must refrain himself to live as an internal alien in a world shaped by the state of power.

The above argument (which goes against the terrorists) is found to be 'inhuman'. As here an implication is made to dump the terrorists within such a torturous Government; keeping them alienated and unnoticed only because they lack strength to confront the state and its machinery. This means either one has to be powerful to come into the scenario or he has to suffer by being tortured by the power, if he is lacking it. This is what the Major premise of the argument attempts to state. Since the terrorists have no power (as they are bad lives, marginal or minority), thus they should refrain the idea of attracting the attention of the Government; even for making their claims of getting basic necessities heard by the Government. It is here where the Government requires to show them care; by bringing them nearer, patiently listening to their problems even if it cannot solve them all at once, thereby making them feel that like others they are also citizens of the nation who have equal rights - instead of simply drowning them neck-deep into the problem.

If we look into the logic of the terrorists then their acts can be meaningfully and innovatively conceptualized as 'moral' in the sense that they are guided by circumstantial or situational rightness or wrongness. Moral actions including that of 
terrorism result from both rational deliberation and experiential (habituation) processes, themselves the outcome of the interaction between individual and environment - specifically the interaction between a person's morality and moral context in which he or she operates.

Now the question is why do these terrorists break rules?

It can be said that an individual as a terrorist breaks a law in part because they judge it to be morally wrong or because they think it does not apply in a particular moral context, in other words law-breaking occurs when there is a lack of correspondence between the law and the individual's moral values in a given context as per situational action theory which by setting a logic of the terrorists hold terrorism as moral.

Such a logic can only be realized when we step out of our domain of Universalized theories of traditional ethics, which values no situation merely generalizing rules of morality equally for all. It is here where care ethics compensates for the gap.

The above logic of terrorism can only be felt by us if this problem is perceived with a vision of care.

But in spite of all such arguments of care in favour of the terrorists I would like to mention here that, as care and compassion are required by us to realize their logic, they should also take care so that in their attacks no innocents are killed. Although they would not consider us to be innocents as we elect and re-elect the corrupt Government but what about the children, handicapped physically as well as mentally, old and infirm - why do they have to die in their attacks, as they are in no way related to their cause? The terrorists would claim that to be Collateral damage as found in wars too. But it can be retorted back that in wars the direct target is the party at dispute and not the innocents like in terrorism. On such grounds at least some amount of care can also be expected from them to us. Another thing I would like to mention here; during hijacking and hostage taking by the terrorists, if we impart the virtues of care and compassion instead of using violence then it would only take lives of many innocents. Again for those who see terrorism as a lucrative profession or act of power struggle to remove the present Government to come into power not by election but by force or those who undergo terrorism to get their selfish interests served; in these cases care and compassion would not help. (As here their sufferings do not seem to be 'undeserved'.)

In order to understand the sufferings of others and be caring and compassionate towards them in the appropriate sense, and also realize the meaning of correct application of individuality and human-dignity, the individuals should be trained accordingly right from the childhood. Proper education, not only textual but also informal such as understanding the feelings and sentiments of others, not over valuing material goods or objects which bring one into competition, should be given to the children. In the Indian backdrop, the saints and the enlightened beings realized this truth. In the Buddhist tradition we find the mention of Brahmavihāra. According to Mettā Sutta, Shākyamuni Buddha held that the cultivation of four 'immeasurables' has the power to cause the practitioner to be reborn into a Brahmaloka, where he could be eradicated from all sufferings and can enjoy eternal bliss. The mediator is instructed to radiate out to all beings in all directions, the mental states of (1) loving kindness or benevolence (maîtreyee) (2) compassion (karu $n \overline{\mathbf{a}}$ ) (3) empathetic joy (muditā) (4) and equanimity (upekkhā). 
Let us now state what each virtue implies:--

1. Loving-kindness (maîtreyee) towards all: Reflects the hope that a person will be well--the wish that all sentient beings, without any exception, be happy.

2. Compassion (karu $n \overline{\mathbf{a}}$ ): Implies that a person's sufferings will diminish--wishes for all sentient beings to be free from sufferings.

Empathetic joy (muditā): Reflects joy in the accomplishment of a person oneself or another. It is the wholesome attitude of rejoicing in the happiness and virtues of all sentient beings.

3. Equanimity (upekkhā): Is a process of learning to accept loss and gain, praise and blame, and success and failure, all with detachment, equally for oneself as well as for others. Equanimity is not to distinguish between friend, enemy or stranger, but regards every sentient being as equal. It is a clear minded, tranquil mental state, not being overpowered by delusions, mental dullness or agitation.

Among these four we would now talk about compassion or Karu $n \bar{a}$. The word Karu $n \bar{a}$ means sacrificing one's pleasure for the others who are suffering. In other words Karu $n \bar{a}$ means to help others even at the cost of one's own suffering.

Karu $n \bar{a}$ or compassion has a great strength within it. It acts as a medicine to physical or mental distress. It has a huge healing power. It has been found in many cases that Karu $n \bar{a}$ itself has helped many people to come out of their poor conditions, even without any external aid or assistance (as found in the Jātaka tales).

Now, it is very important for us to know to whom should be Karu $n \overline{\mathrm{a}}$

appropriately shown ${ }^{2}$. It should not be shown to our kin and kith because they would automatically get it from us. Buddha says that it should be shown to the suffering souls, suffering due to ill health, poverty, natural calamity, loss of material property or family members and so on. Moreover to our surprise we should be compassionate even to the happy-go-lucky persons who do not know that their happiness would end shortly, as mentioned by Buddha.

Buddha further states that by practicing small acts of compassion or Karu-

$n \overline{\mathrm{a}}$, Mahaakaru $n \overline{\mathrm{a}}$ or Bodhi develops for the human race at large and Buddha was a living example of that.

Now how do we practice this Karu $\boldsymbol{n} \overline{\mathrm{a}}$ ? First and foremost before spreading it to the others we need to imbibe it within ourselves through regular meditation. We thus start by meditating upon compassion towards ourselves, then for near and dear ones, then for those whom we know and finally for our not so well-wishers or enemies. This is how it can be spread to the whole world by its regular practice over the years. (Visuddhimagga, Chapter ix)

One authentically Buddhist candidate for the necessary foundation for human right is compassion ( Karu $n \bar{a}$ ). The Buddhist virtue of compassion encourages us to develop the human capacity for empathy to the point where we can identify fully with the suffering of others. The eighth chapter of the Bodhichaaryavatara, speak of 
'exchanging self and other' and recommends a meditational practice in which we imaginatively place ourselves in others' situation so that their predicament seems as real to us as it does to them. A number of commentators have suggested that compassion provides a Buddhist foundation or, perhaps, a replacement for human rights and regard it as preferable in two ways: first, because it has an authentic Buddhist pedigree; and secondly, because it is directed outwards to others rather than towards oneself.

Peter Harvey in his books An Introduction to Buddhist Ethics and An Introduction to Buddhism considers the foundations of Buddhist ethics. As Buddhists come to realize the extent of dukkha in their own lives, and how it is caused by their response to life's happenings, the natural human feeling of sympathy (anukampa) for others-solidarity with them in the shared situation of dukkha-is elicited and deepened. Accordingly, the importance of comparing oneself with others is stressed, yearning for happiness and recoil from pain - for both self and others.

In a more general context the Buddha is also reported to have said: 'Having traversed the whole world with my thought, I never yet met with anything that was dearer to anyone than his own self. Since the self of others is dear to each one, let him who loves himself not harm another' (Udaana 47). Thus on finding some boys tormenting a snake and poking it with sticks, the Buddha said:

All tremble at punishment,

Life is dear to all.

Comparing others with oneself,

One should neither kill nor cause to kill

(Dhammapada 130)

The Buddha once goes on to tell a story to two parties of monks quarrelling over the interpretation of a point of monastic discipline. The story states, Dighavu the son of king Brahmadatta of Kaasi, were once instigated to take revenge against the king who killed his father. Dighavu then says:

My parents were killed by a king but if I were to deprive the king of life, those who desired the king's welfare would deprive me of life and those who desired my welfare would deprive these of life; thus enmity would not be settled by enmity. (Vinaaya Pitaakaa 1.348)

\section{PRACTICAL IMPLEMENTATIONS OF THE BRAHMAVIHAARAS BY BUDDHISTS IN DIFFERENT NATIONS.}

We can see many instances where love, compassion, care and non-violence are taking the shapes of peace in the modern world. In Burma, Aung San Suu Kyi is noted for her spirited opposition to the country's oppressive Marxists-Nationalist regime, which ignored her party's resounding victory in the 1990 elections. In Thailand, Sulak Sivaraksa founded many grass root non-governmental organizations for peace, human rights, community development and ecumenical dialogue, and objected to coups by the army (Sivaraksa, 1986; Swearer, 1996:1980). An exile in France since the 1970s, he is a prolific writer on Buddhism and peace, and a strong advocate of 'Engaged Buddhhism'. Another exile, the Dalai Lama, has become a 
world-wide symbol of Buddhist values. Buddhist activities for peace are also found in Japan, Sri Lanka and Cambodia.

According to Buddhist psychology, most of our troubles are due to our passionate desire for and attachment to things that we misapprehend as enduring entities. The pursuit of objects of our desire and attachment involves the use of aggression and competitiveness. On being sunken in such competition we become blind and thus do not see the suffering of bad lives or of those who fail to obtain such objects. Dalai Lama as brought up in the Mahayana Buddhist tradition tries to solve such an inequality and violence leading from it, by 'love' and 'compassion' - which according to him are the moral fabric of world peace.

The rationale for compassion as he mentions is that every one of us wants to avoid suffering and gain happiness. This in turn, is based on the valid feeling of 'I', which determines the Universal desire for happiness. Indeed, all beings are born with similar desires and should have an equal right to fulfil them. He further states ${ }^{3}-$

"If I compare myself with others, who are countless, I feel that others are more important because I am [...] one person whereas the others are many $[\ldots]$

Whether one believes in religion or not, there is no one who does not appreciate love and compassion.

When we take into account a longer perspective, the fact that all wish to gain happiness and avoid suffering, and keep in our mind our relative unimportance in relation to countless others, we can conclude that it is worthwhile to share our possessions with others. When you train in this sort of outlook, a true sense of compassion - a true sense of love and respect for others-becomes possible. Individual happiness ceases to become a constant self-seeking effort; it becomes an automatic and far superior by-product of the whole process of loving and serving others."

Now let us logically try to prove the requirement of compassion. The arguments offered by Shantideva consists of a chain of arguments which may be stated formally thus-

1. I have life (sattva)

2. Others have lives.

Therefore, others are similar to me.

3. I have to favour (anugraha) myself

Therefore, I have to favour others also

4. I favour myself in the form of removing my suffering

Therefore, I have to favour others also by removing their suffering.

Therefore, I must have compassion for others when I see others suffer.

'Thus to put in a formalized manner it becomes easy to realize that the feeling of compassion consists in the feeling of pain at the sight of other's suffering. (Ref. Morality And Religion: Some Reflections. Ed. By Aparna Banerjee and Shilpita Mitra. Article: 'Buddhist notion of Compassion and Care Ethics' by Madhumita Chattopadhyay. P. 106, 107). 
If the Government as well as the citizens can be really caring and compassionate towards the exploited classes of the society then perhaps the terrorists would understand that there are people beside them to think about them, to pay care and compassion to them and hence they would perhaps stop this violence and blood-shed on earth.

Governmental Measures of Care and Compassion to the terrorists

Before coming to the measures of the Government, first let us track the types of terrorism which would at one breath tell us the major underlying causes of this phenomenon.

The contemporary terrorism found today can be streamlined to three main categories: Religious terrorism, Economic terrorism and Sociopolitical terrorism as found in Sanu Bhattacharya's book Terrorism and Moral Questions (Milinda De for Levant Books, Kolkata, 2007).

In Religious terrorism we find that there is some religion on earth who believes that all other religions are false and superfluous. Thus people should follow only that particular religion or else they have no right to live.

Economic terrorism arises due to poverty resulting from suppression of the lower class by the upper. The Capitalists or Bourgeois generate profit by taking away the extra wages earned by the proletariats on working for more hours, thereby becoming richer day by day making the poor, poorer.

The Socio-political terrorism occurs because of Colonialism, Military occupation, Dictatorial Government or it leads to a war for Sovereignty or National liberty, sometimes supporting Separatist movement.

We would now go on to assess what the Government can do to overcome such causes of terrorism using Care and Compassion.

The care and compassion which are required to be imbibed by us to help the deprived lot should not only be kept within us but should also be executed properly to them, in practice. First and foremost education is to be given to them free of cost till 14 years of age as already has been mentioned in the Directive Principles of Indian Constitution. The religious terrorism that takes place is mostly due to the wrong interpretations of Quran by the Maulvis in the Madrasas who state that anyone who does not follow Allah is a Kafer and hence should be killed. No God of any religion can talk of innocent killing. 'Jihad' in Quran means a struggle against oppression and not killing of innocents or killing of Hindu, Buddhist etc. If children are given education then they can read Quran themselves and understand its truth instead of depending on others who get an opportunity of brainwashing the energetic new comers by getting their own jobs done.

Moreover proper education given to them would also give them a clear picture of the Socio-political problems of our country, now and then. The lives of great personalities, their strategies during same crisis, a feeling of patriotism, how these personalities fought to protect our nation-if such things are taught to the future citizens then their perspective towards solving a struggle against oppression would change altogether. Then perhaps terrorism would take the form of Revolution enjoying public support.

Next, the Government should execute policies where basic economic security would be sanctioned to the bad lives. Today even such facilities 
are given by the Government to the BPL card holders whereby they get jobs and their basic necessities are also served. But the problem here is, those who are really living in a poverty-stricken zone are simply unnoticed; they do not get such facilities due to lack of communication and connectivity to proper towns, cities or nearby villages. And those who are well off are found to enjoy such privileges as they have direct connections with the Government. Here I would like to mention that along with primarily educating the mass, anti-corruption campaigns should be conducted frequently as well a value based educational system has to be introduced.

Constitutionally, the Government can incorporate some articles especially for those who tend to become terrorists in future; which would give them privileges for sustenance of lives which are 'bad', 'cut-short' and 'underprivileged'. Even today we find articles in Indian Constitution providing some extra privilege to the handicapped, schedule classes, schedule tribes and other backward classes in case of education and employment. But apart from them the bad lives include a lot much variety and need a lot more other securities apart from job and education. Most importantly after formulating such laws they have to be informed to the bad lives for their utilization, as often they remain in the dark due to lack of political awareness and that of education. And those who can do without it are found to forge certificates to get such back up.

The legislative body of the Government should form certain statutes and agendas such as providing drinking water, electricity to the rural zones; creating connectivity between the interiors and their near most subdivision, district, town and village. Again setting up public toilets to maintain good health and hygiene of this deprived lot and ensuring them with security during emergencies also come under this list. Not only so health centers can be made for free checkups of pregnant mothers, before and after delivery, women, children, old and infirm providing them with required medicines at low rate or free of cost.

The readers might think that such a plan would require a huge amount of budget especially for a country like India. The question now arises does our nation not have that money, then how come billions are going into Swiss bank? At this juncture bad lives, marginal revolt and become subalterns and finally terrorists pointing out that the Government and the privileged classes of the society through wrong means acquire more and more by depriving the poor so much so that even in a civilized nation after 68 years of independence a huge section lives without food, shelter and clothing.

Next, an executive Committee should be set up to find out whether rights and laws formed by the legislative body of the Government are indeed executed to the bad lives and are not misused by the well-off.

Finally the judiciary should punish those who break such laws or in other words abandon those who do not let them enjoy these rights.

Repeated studies have shown that terrorism is not directly a product of poverty and religion as terrorism is mostly found in middle income countries than in Third world countries, and religion is just eyewash 
whose main drive is political. Thus more than economic and religious causes terrorism is found due to denial of human rights and Military occupation - both of which come under socio-political cause. A high percentage of terrorists come from nations lacking political freedom. Palestinian terrorists, those from Iraq and Sri Lanka irrespective of their religion and group involved, they fight for a different cause altogether.

The Government here has to take care not only of the fact whether the terrorists get the rights formed for them by the Government but also the respective Governments of different nations should take care of the fact whether every part of each nation can breathe sovereignty from its surrounding environment. Military occupation often carries out a dictatorial form of ruling where the citizens get no freedom at all. They are sometimes even discarded from their own lands by these foreign occupants. This affects the direct rights of human beings where they are treated as means and in the process Human Dignity is affected.

These above measures of the Government would perhaps be able to take care of Religious, Economic and Socio-political causes of terrorism to some extent. Here the common citizens who are not seen as "innocents" by the terrorists also have a role to play as Ted Honderich suggests in his book After the Terror. We who are much privileged can cut down our extravagances of life and sacrifice them for their cause. We can stretch our hand of help to them by changing the Government when seemed to be corrupt (as in a democracy public opinion plays a very important role). In this way we do not only seem to imbibe virtues of care and compassion within us but also can execute them towards the so-called terrorists to make them feel that we are beside them.

I want to conclude here by mentioning that apart from all such practical measures taken we must also emphasize on spiritualism which was once the strength of India; even feared by the Missionaries of West who came to win us over. Such spiritualism imbibes care, compassion in us and helps us to understand the oneness of all beings underlying their external appearance. But the problem is that today people understand the notion of global village but they fail to understand global oneness. At least they would all agree with me when I say that the same pain is felt when inflicted on other irrespective of religion, class and creed as would have been felt by me if I was injured. This understanding is enough to curb terrorism as one has to remember that what he is doing today would come back to him tomorrow as per the law of nature. And if he wants to save himself then he should behave in the way he wants others to behave with him. This Golden Rule of Life perhaps entails all virtues of love, affection, care and compassion. Thus if a genuine initiative is taken to impart compassion and care for each other or help and save each other from suffering (be it terrorists or us) then perhaps the above mentioned problem which takes the form of today's epidemic would be perpetually solved. With such a note of optimism I would end my paper here, as pessimism would only aggravate the problem.

Many may think that Care and Compassion are mere virtues and not acts; hence terrorism cannot be solved by them. But it has to be remembered that whatever great deeds the world witnesses show a background pregnant with care and compassion. Without care and felling for the act, motivation to do it 'as if it is mine' would never come. The greatest example is that of a mother who cares for her child not because it is her 
duty or because it serves maximum benefit to her or the society, but she does so out of her instinct as if the child and she are inseparable. Thus here the feeling of oneness in care motivates her to go to extremes to 'do' anything for him. So it is not true that Care and Compassions are mere virtues which generate no productivity.

Hence I believe that Care and Compassion if used properly then they can act as the Ultimate solution of terrorism in a violence driven world where counter-terrorism is already back firing.

\section{References}

1. Carol Gilligan, In a Different Voice, Cambridge, Mass: Harvard University Press, P.28, 1982 .

2. Mahārshi Sayadaw, Brahmanvihāra Dhamma, Socialist Republic of the Union of Burma: Sasananuggaha Organization, P.280, July, 1985.

3. Dalai Lama, Peace and Conflict Studies, Ed. by Charles P.Webel and Jorgen Johansen, London-New York: Rutledge, [Chapter-11 'A Human Approach to World Peace' by Dalai Lama], 2012.

\section{Bibliography}

1. An article namely 'Compassion and Caring: Integral Features of Emotional Well Being' by Robert Brooks. (www.drrobertbrooks.com/monthly, as retrieved on 25.7 .14 at $3.10 \mathrm{pm}$ )

2. Virgina Held, The Ethics of Care: Personal, Political and Global, U.K: Oxford University Press, 2005. 